\title{
ION FLUXES OF Metynnis hypsauchen, A TELEOST FROM THE RIO NEGRO, AMAZON, EXPOSED TO AN INCREASE OF TEMPERATURE
}

\author{
BALDISSEROTTO, B. ${ }^{1}$ and VAL, A. L. ${ }^{2}$ \\ ${ }^{1}$ Departamento de Fisiologia, Universidade Federal de Santa Maria, CEP 97105-900, Santa Maria, RS, Brazil \\ ${ }^{2}$ Laboratório de Ecofisiologia e Evolução Molecular, Instituto Nacional de Pesquisas da Amazônia, \\ CEP 69083-000, Manaus, AM, Brazil \\ Correspondence to: Adalberto L. Val, Laboratório de Ecofisiologia e Evolução Molecular, Instituto Nacional de \\ Pesquisas da Amazônia, Avenida André Araújo, 2936, CEP 69083-000, Manaus, AM, Brazil, \\ e-mail: dalval@inpa.gov.br \\ Received July 11, 2001 - Accepted August 8, 2001 - Distributed November 30, 2002
}

(With 2 figures)

\begin{abstract}
The aim of this study was to investigate the effect on an increase of temperature on the net ion fluxes on Metynnis hypsauchen, a teleost species from the Rio Negro. Fish were collected in the Anavilhanas archipelago, Rio Negro, Amazon. After $24 \mathrm{~h}$ adaptation fish were placed in individual chambers served with a steady flow of recirculated water. $\mathrm{Na}^{+}$and $\mathrm{Cl}^{-}$fluxes were determined at 26 and $33^{\circ} \mathrm{C}$. After $18 \mathrm{~h}$ in the chambers, fish presented an influx of $\mathrm{Na}^{+}$and $\mathrm{Cl}^{-}$, and the temperature raise to $33^{\circ} \mathrm{C}$ led to an efflux of both ions, which remained even after $6 \mathrm{~h}$ in this temperature. Six hours were not enough to promote a significant reduction of net ion effluxes, but certainly the fluxes would be in net balance after a longer period of time, since this species can be exposed to this temperature in its natural environment.
\end{abstract}

Key words: Metynnis hypsauchen, temperature, ion fluxes.

\section{RESUMO}

Fluxos iônicos em Metynnis hypsauchen, um teleósteo do rio Negro, Amazonas, exposto a aumento de temperatura

O objetivo deste trabalho foi verificar o efeito do aumento de temperatura nos fluxos iônicos de Metynnis hypsauchen, uma espécie de teleósteo do Rio Negro, Amazonas. Os peixes foram coletados no arquipélago de Anavilhanas, Rio Negro, Amazonas. Após adaptação de 24 h, os peixes foram colocados em câmaras individuais com fluxo constante de água recirculada. Os fluxos de $\mathrm{Na}^{+} \mathrm{e} \mathrm{Cl}^{-}$ foram determinados a 26 e $33^{\circ} \mathrm{C}$. Após $18 \mathrm{~h}$ nas câmaras, os peixes apresentaram influxo de $\mathrm{Na}^{+} \mathrm{e}$ $\mathrm{Cl}^{-}$, e o aumento da temperatura para $33^{\circ} \mathrm{C}$ provocou efluxo de ambos os íons, o qual se manteve mesmo depois de $6 \mathrm{~h}$ nessa temperatura. Seis horas não foram suficientes para promover redução significativa dos efluxos iônicos, mas certamente esses fluxos atingiriam equilíbrio após um período mais prolongado, uma vez que essa espécie é regularmente exposta a essa temperatura em seu ambiente natural.

Palavras-chave: Metynnis hypsauchen, temperatura, fluxos iônicos. 


\section{INTRODUCTION}

Fish of the Rio Negro, a tributary of the Amazon River, are exposed to extremely dilute waters, low $\mathrm{pH}$ and buffering capacity, and large amounts of organic compounds (Furch, 1984). The mechanisms involved in the resistance of these fishes to such water seems to be a high branchial affinity for $\mathrm{Ca}^{++}$or some interaction of the organic compounds to the branchial tight junctions, both avoiding the increase of branchial ion permeability (Gonzalez et al., 1998).

Temperature changes alter the noncovalent forces that stabilize biological membranes and interactions among proteins (Hazel, 1993), and apparently influence branchial ion permeability in rainbow and lake trout (Gonzalez \& McDonald, 1994). Therefore, the aim of this study was to investigate the net ion fluxes on Metynnis hypsauchen, a teleost species from the Rio Negro, when exposed to an increase of temperature.

\section{MATERIAL AND METHODS}

Specimens of Metynnis hypsauchen (Serrasalmidae) (40-120 g) were collected with drift nets in the Anavilhanas archipelago, Rio Negro, Amazon. Fish were kept without feeding in a running $1,000 \mathrm{~L}$ freshwater tank $\left(27-28^{\circ} \mathrm{C}\right)$ for at least $24 \mathrm{~h}$. Measured water composition was (in $\mu \mathrm{M} \mathrm{L}^{-1}$ ): $\mathrm{Na}^{+}, 12.3 ; \mathrm{Cl}^{-}, 34.9 ; \mathrm{pH} 6.37$.

After adaptation fish were placed in individual chambers $(850 \mathrm{ml})$ served with a flow of 110

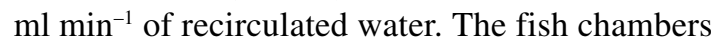
were housed on a wet table that drained water back into the recirculation reservoir. Total volume of the system, serving a maximum of 4 fish, was 50 L. The chambers were operated as closed systems (with aeration) for $120 \mathrm{~min}$ at 2, 6, and $18 \mathrm{~h}$ after the transference of the fish. Water samples $(5 \mathrm{ml})$ were taken at the beginning and end of this time for analysis of $\mathrm{Na}^{+}$and $\mathrm{Cl}^{-}$concentrations.

In another series of experiments, fish were maintained $18 \mathrm{~h}$ in the chambers before collecting water samples for analysis of $\mathrm{Na}^{+}$and $\mathrm{Cl}^{-}$ concentrations as explained before. After the first collection, temperature was raised from $26^{\circ} \mathrm{C}$ at about $1^{\circ} \mathrm{C} \mathrm{h}^{-1}$ (rate of temperature increase suggested by Elliott, 1991) to a final temperature of $33^{\circ} \mathrm{C}$ (M. hypsauchen died at higher temperatures in this experiment). Water samples were collected when temperature reached $33^{\circ} \mathrm{C}$ and six hours later. $\mathrm{Na}^{+}$concentrations were measured with a B262 flame spectrophotometer (Micronal), and $\mathrm{Cl}^{-}$ concentrations were measured by the colorimetric assay of Zall et al. (1956). Ion fluxes were calculated according to Gonzalez et al. (1998).

Temperature and oxygen measurements in the Rio Negro were determined with an oxygen meter YSI, model 55. The measurements were made near the drift nets in the Lago do Prato, Anavilhanas archipelago, at several depths, and every $4 \mathrm{~h}$ for one day.

Homogeneity of variances was verified by the Bartlett test, and net ion fluxes at different times were compared by one-way analysis of variance and Tukey test, with the aid of the GraphPad Instat program (version 2.05a). Data were expressed as mean \pm SEM, and the minimum significance level was $\mathrm{p}<0.05$.

\section{RESULTS AND DISCUSSION}

Oxygen levels usually were in the $5.0-6.5 \mathrm{mg} /$ $\mathrm{L}$ range, and temperature range was $29.7-34.3^{\circ} \mathrm{C}$. Higher oxygen levels and temperature were observed at 12:00-16:00 h, while lower values were determined at 4:00 h. Depth of water column did not influence temperature, but oxygen levels were $0.3-1.0 \mathrm{mg} / \mathrm{L}$ higher at surface than bottom $(0.5-1.0 \mathrm{~m})$.

There was a net loss of $\mathrm{Na}^{+}$and $\mathrm{Cl}^{-}$in the first $6 \mathrm{~h}$ of maintenance of $M$. hypsauchen in the chambers. After $18 \mathrm{~h}$ a slight influx of these ions could be detected (Fig. 1). In the other experiment, after $18 \mathrm{~h}$ (control) there was also an influx of $\mathrm{Na}^{+}$ and $\mathrm{Cl}^{-}$, and the temperature raise to $33^{\circ} \mathrm{C}$ led to an efflux of both ions, which remained even after $6 \mathrm{~h}$ in this temperature (Fig. 2).

The $\mathrm{Na}^{+}$and $\mathrm{Cl}^{-}$effluxes observed at the first hours after confinement of $M$. hypsauchen in the chambers was expected, since stress of handling or confinement led to an increase of branchial ion efflux in some teleosts species (McDonald et al., 1991).

The augmentation of temperature to $33^{\circ} \mathrm{C}$ increased net $\mathrm{Na}^{+}$and $\mathrm{Cl}^{-}$efflux in M. hypsauchen. An increase in water temperature increased gill ventilation and heart rate in some teleosts (Hazel, 1993; Fernandes et al., 1999). 
The increase of these physiological parameters could lead to an elevation of the branchial perfusion pressure, promoting an increase of the lamellar flow, and a higher oxygen uptake. Both situations can promote an augmentation of ion loss (Gonzalez \& McDonald, 1992, 1994). An increase of $\mathrm{Na}^{+}$loss was also observed in Oncorhynchus mykiss and lake trout after an increase of water temperature from 10 to $18^{\circ} \mathrm{C}$. However, since there was a much greater effect of temperature on $\mathrm{Na}^{+}$ efflux than on oxygen uptake, the authors supposed that the highest temperature could affect the gill epithelial membrane (Gonzalez \& McDonald, 1994). Perhaps the same mechanism would be responsible for the increase of ion effluxes in $M$. hypsauchen at $33^{\circ} \mathrm{C}$. Six hours were not enough to promote a significant reduction of net ion effluxes, but certainly the fluxes would be in net balance after a longer period of time, since this species can be exposed to this temperature in its natural environment. The maintenance of the ion effluxes at this level would lead to the death of the fish in a few days. Additional studies are needed to solve these doubts.

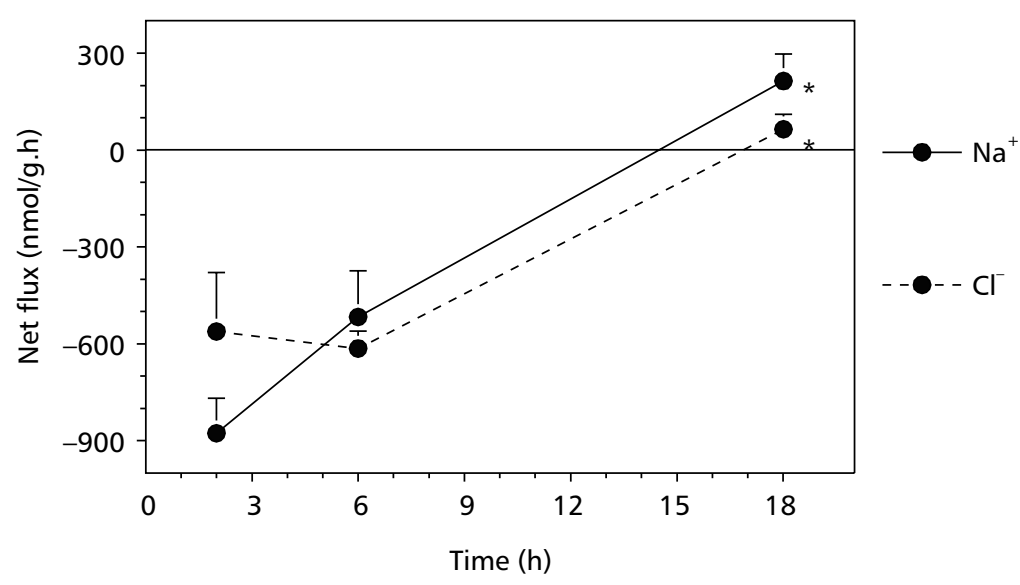

Fig. 1 - Net $\mathrm{Na}^{+}$and $\mathrm{Cl}^{-}$fluxes of Metynnis hypsauchen as a function of time after maintenance in the chambers. Asterisks indicate significant difference of fluxes $(\mathrm{p}<0.05)$ at $18 \mathrm{~h}$ from previous measurements.

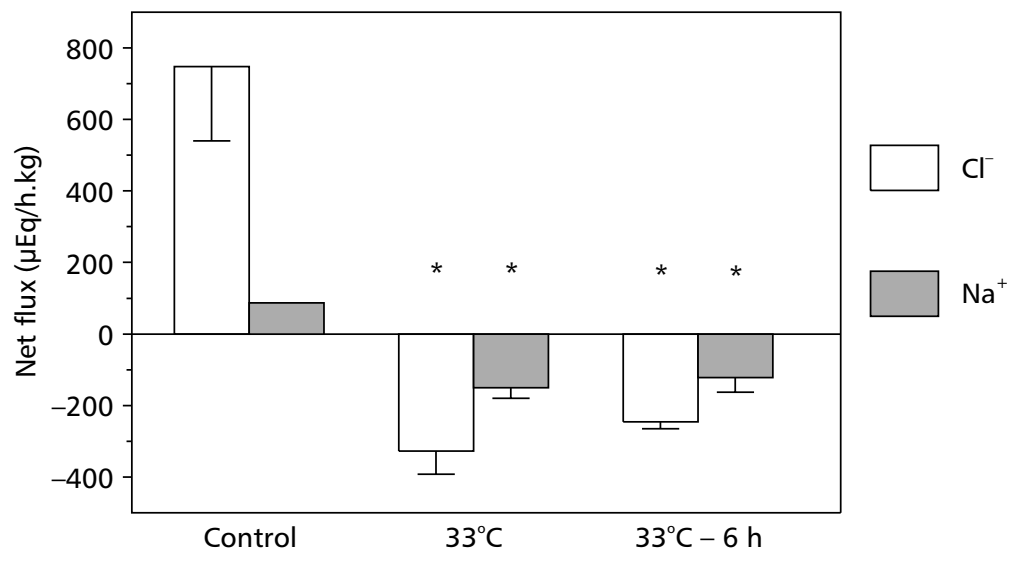

Fig. 2 - Effect of temperature on net $\mathrm{Na}^{+}$and $\mathrm{Cl}^{-}$fluxes of Metynnis hypsauchen. Asterisks indicate significant difference $(\mathrm{p}<0.05)$ from control. 


\section{REFERENCES}

ELLIOTT, J. M., 1991, Tolerance and resistance to thermal stress in juvenile Atlantic salmon, Salmo salar. Freshwater Biology, 25: 61-70.

FERNANDES, M. N., SANCHES, J. R., MATSUZAKI, M. PANEPUCCI, L. \& RANTIN, F. T., 1999, Aquatic respiration in facultative air-breathing fish: effects of temperature and hypoxia, pp. 341-352. In: A. L. Val \& V. M. F. Almeida-Val (ed.), Biology of tropical fishes. INPA, Manaus, 460p.

FURCH, K., 1984, Water chemistry of the Amazon basin: the distribution of chemical elements among freshwaters, pp. 167-199. In: H. Sioli (ed.), The Amazon: limnology and landscape ecology of a mighty tropical river and its basin. Junk, Dordrecht.

GONZALEZ, R. J. \& McDONALD, D. G., 1992, The relationship between oxygen consumption and ion loss in a freshwater fish. J. Exp. Biol., 163: 317-332.
GONZALEZ, R. J. \& McDONALD, D. G., 1994, The relationship between oxygen uptake and ion loss in fish from diverse habitats. J. Exp. Biol., 190: 95-108.

GONZALEZ, R. J., WOOD, C. M., WILSON, R. W., PATRICK, M. L., BERGMAN, H. L., NARAHARA, A. \& VAL, A. L., 1998, Effects of water $\mathrm{pH}$ and $\mathrm{Ca}^{+2}$ concentration on ion balance in fish of the rio Negro, Amazon. Physiology, 71(1): 15-22.

HAZEL, J. R., 1993, Thermal biology, pp. 427-467. In: D. H. Evans (ed.), The physiology of fishes. CRC, Boca Raton, 592p.

McDONALD, D. G., CAVDEK, V. \& ELLIS, R., 1991, Gill design in freshwater fishes: interrelationships among gas exchange, ion regulation, and acid-base regulation. Physiological Zoology, 64(1): 103-123.

ZALL, D. M., FISHER, M. D. \& GARNER, Q. M., 1956, Photometric determination of chlorides in water. Analytical Chemistry, 28: 1665-1678. 